ers have applied for a patent on the recombinant virus on behalf of the U.S. goverment, which funded this research.

Development of effective hepatitis vaccines has been hampered because hepatitis $\mathrm{B}$ virus cannot be grown in cultured cells or in animals other than chimpanzees. Also, there are no attenuated (non-pathogenic) strains of hepatitis B that can be used for vaccination. Merck Sharp \& Dohme recently marketed a hepatitis vaccine that consists of $\mathrm{HBsAg}$ isolated from the blood of infected humans. The isolation process is tedious and expensive. Consequently, the vaccine is costly, about $\$ 100$ per immunizing dose. Several research groups have genetically engineered bacteria, yeast, and animal cells to produce $\mathrm{HBsAg}$. However, the antigen must still be isolated and purified before use.

A vaccinia-hepatitis vaccine could be produced much more inexpensively than its current competitor. For example, Wyeth Laboratories currently sells freeze-dried smallpox vaccine, the model for the future vaccinia-hepatitis vaccine, for about $\$ 0.31$ per dose. While current production levels are low, scientists at Wyeth foresee no problems in scaling up production of vaccinia-based vaccine production. reassuring, because if you are going to inoculate a live vaccine into someone we would like to have it be a virus we know something about," said Gerald Quinnan, director of the Division of Virology at the FDA. He added that if vaccinia was used as a gene carrier for viral antigens such as the HBsAg, "safety would not be a major
"The use of vaccinia is certainly

issue as long as reasonable experiments showed that putting the foreign genes into vaccinia didn't make it virulent in some new way." Quinnan emphasized, however, that he could not predict how swiftly the approval process would move without knowing the vaccine's infectivity or its ability to raise an immune response.

Panicali and Paoletti report that genes from RNA viruses such as influenza can also be engineered into and expressed by vaccinia. They constructed a complementary DNA copy of the influenza hemagglutinin (HA) gene and inserted it into vaccinia DNA. The resulting recombinant vaccinia-influenza virus produces an anti-HA immune response in rabbits.

"We think useful vaccines can be developed for rabies, herpes, footand-mouth disease, and many other viruses," Panicali said, noting that their laboratory is undertaking this work. They have filed patent applications covering both the techniques and the vaccine strains on behalf of the New York State Department of Health.

Both Moss's group and Panicalli and Paoletti have evidence that relatively large segments of DNA, at least 25 kilobases $(\mathrm{kb})$, can be inserted into the vaccinia genome without interfering with viral infectivity. (The $\mathrm{HBsAg}$ insert is about $1.4 \mathrm{~kb}$ and the $\mathrm{HA}$ gene insert is about $1.7 \mathrm{~kb}$.) The researchers are hopeful that the large capacity will allow simultaneous insertion of many genes for foreign antigens. The resulting vaccinia-based recombinant virus could then be used as a polyvalent vaccine that would immunize against a broad spectrum of viral diseases.-Mitchel Zoler and Tazewell Wilson

\section{INIt:HATONA FIMNC}

\section{MERRILL LYNCH LAUNCHES SCI/TECH MUTUAL FUND}

NEW YORK, NY-Sci/Tech Holdings, the new international mutual fund specializing in technology stocks, completed its subscription period March 24 and began investing funds in April. Specializing in promising science and technology investments, including biotechnology, Sci/ Tech hopes to capitalize on the explosive growth of some companies in these industries.

The fund is run by a trio of respected firms: Merrill Lynch Asset Management (New York) manages the fund and is the North and South American investment advisor; Nomura Capital Management (Tokyo) advises on Japanese and Pacific Basin investments; and Lombard Odier International Portfolio Management Limited (London) is the advisor for
Tech holdings and $\$ 285$ million into $\mathrm{Sci} /$ Tech S.A. Although this is easily the largest initial endowment of any mutual fund in history, it is somewhat below the billion dollar total that some analysts had predicted. Still, a Merrill Lynch spokesman says its customers "were extremely enthusiastic and the fund was well received."

$\mathrm{Sci} / \mathrm{Tech}$ says it plans to look into biotechnology companies working in health care, pharmaceuticals, agriculture, food production, and chemicals. But for the moment, Merrill Lynch officials are reluctant to disclose specific industries and companies in which the fund is investing, saying that such statements would be premature and would not be in the best interests of the fund. The premier quarterly report, expected in midsummer, should yield the first good look at exactly where the $\$ 835$ million is going.

According to the fund's prospectus, it will put at least 80 percent of its assets into science and technology industries, and will hold equity in companies at varying stages of development. Up to 10 percent of its assets may be invested in venture capital propositions-possibly including limited partnerships-but initially the fund expects to invest very lightly in this way. At no time, the fund says, will it commit more than 25 percent of its assets to any one industry. This diversification in terms of nationality, stage of development, and industry reduces risk, the prospectus notes. The fund is oriented toward longterm rather than short-term gains.

Takao Nakumura, senior vice president and director of Nomura Capital Management, says that for Japanese biotechnology investments, "generally speaking, we are looking at established companies," especially food and drug companies. The fund will make no venture capital investments in Japan for the time being. Actual investments, he says, will depend on such factors as each company's stock outlook, the overall market, and the yen exchange rate.

The idea of technology-oriented mutual funds is not new: Fidelity Select Technology, the Medical Technology Fund, and the New Horizons Fund have already invested over a billion dollars, most of it in technology- or science-related companies. In addition, Citibank N.A. is creating an Emerging Health Care Fund. James B. Hoover, a Citibank vice president and manager of the new fund, says that up to 15 percent of its portfolio will be committed to biotechnology. Citibank's fund is expected to raise over $\$ 100$ million for investment by the end of the year, but it will not have Sci/Tech's international scope. 